\title{
ANALISIS BENZOIL PEROKSIDA DALAM TEPUNG TERIGU
}

\author{
Vina Juliana Anggraeni ${ }^{1 *}$, Mutiara Esya Ariestika ${ }^{2}$ \\ 1. Sekolah Tinggi Farmasi Bandung, Bandung-Indonesia \\ 2. Sekolah Tinggi Farmasi Bandung, Bandung-Indonesia
}

*Korespondensi: Vina Juliana Anggraeni | Sekolah Tinggi Farmasi Bandung | vina.juliana@stfb.ac.id

\begin{abstract}
Abstrak
Pendahuluan: Benzoil peroksida merupakan senyawa organik golongan peroksida yang disalahgunakan sebagai pemutih tepung (pematang tepung).Dalam penelitian ini, analisis benzoil peroksida yang terkandung dalam tepung terigu dilakukan dengan menggunakan metode Spektrofotometri Ultraviolet.

Metode: Diperoleh persamaan regresi linier $\mathrm{y}=0,091 \mathrm{x}+0,2425$ sedangkan koefisien korelasinya 0,998. Dari penelitian ini, sampel yang direaksikan dengan larutan KI dalam medium asam serta penambahan suspensi amilum menunjukkan hasil yang positif karena adanya reaksi warna merah keunguan.

Hasil: Dari 6 sampel yang dianalisis, 3 sampel bermerk mengandung benzoil peroksida kurang dari $75 \mathrm{mg} / \mathrm{kg}$ yaitu sampel merk A 28,88 mg/kg; sampel merk B 48,36 mg/kg dan sampel merk C 71,90 mg/kg, sedangkan 3 sampel Non Merk mengandung benzoil peroksida lebih dari $75 \mathrm{mg} / \mathrm{kg}$ yaitu sampel Non Merk A 87,00 mg/kg; sampel Non Merk B 75,07 mg/kg dan sampel Non Merk C 83,52 mg/kg.

Kesimpulan: Pada sampel tepung terigu bermerk kadar Benzoil peroksida kurang dari $75 \mathrm{mg} / \mathrm{kg}$, sedangkan pada sampel tepung terigu non Merk yang beredar kadar benzoil peroksida lebih dari $75 \mathrm{mg} / \mathrm{kg}$. Sehingga dapat disimpulkan sampel tepung terigu non Merk tidak memenuhi syarat.
\end{abstract}

Kata Kunci : Benzoil Peroksida, Spektrofotometri UV, Tepung Terigu.

\section{Diterima 02 Februari 2019; Accepted 30 Juni 2019}

\section{PENDAHULUAN}

Saat ini ada berbagai macam tepung yang tersebar dikalangan masyarakat, seperti tepung tapioka, tepung beras, teping terigu, tepung ketan, tepung maizena dan masih banyak lagi jenis tepung lain nya tepung terigu merupakan jenis tepung yang sering digunakan dalam pembuatan makanan. Terdapat banyak variasi tepung terigu yang ditujukan untuk membuat olahan yang berbeda-beda, seperti roti, kue, mie, martabak, juga berbagai jenis masakan lainnya. (Muchtadi \& Sugiyono, 1992)

Tepung terigu berasal dari biji gandum yang dihaluskan. Dalam proses produksi tepung terigu, setelah biji gandum digiling menjadi tepung terigu, hasilnya tidaklah berwarna putih namun agak kekuningan dan kurang elastis. Terigu semacam ini kurang disukai sebagian besar konsumen karena bila dijadikan adonan kue tidak dapat mengembang dengan baik.Untuk memperoleh terigu yang putih alami dengan mutu yang baik, terigu harus dibiarkan (diperam) selama lebih kurang 4 sampai 6 minggu. Selama masa pemeraman tersebut, bahan-bahan yang menyebabkansifat lekat dan juga pigmen karotenoid akan teroksidasi sehingga akan diperoleh tepung terigu yang berwarna putih dengan daya kembang yang baik. Proses pemeraman ini oleh sebagian produsen terigu dianggap tidak praktis karena memerlukan waktu, sehingga untuk mempercepat proses tersebut biasanya ditambahkan zat pemutih, salah satunya benzoil peroksida. Dengan mencampur benzoil peroksida ke dalam terigu, warnanya akan dilunturkan menjadi lebih putih dalam waktu yang singkat. (Nurmala T, 1980)

Benzoil peroksida ialah senyawa organik dari golongan peroksida.Benzoil peroksida merupakan senyawa oksidator. Benzoil peroksida ini cukup beresiko jika digunakan dalam jumlah banyak karena bisa memicu dan menyebabkan berbagai penyakit. Penggunaan benzoil peroksida tidak di rekomendasikan sebagai bahan tambahan pangan perlakuan tepung, karena tiga alasan, pertama; benzoil peroksida merupakan senyawa reaktif dan mudah mengalami penguraian; kedua, studi klinis memperlihatkan bahwa benzoil peroksida dapat menyebabkan iritasi pada kulit, mata dan saluran pernafasan; dan ketiga bahwa tepung terigu yang ditambahkan benzoil peroksida dapat mengurangi nilai nutrisinya, seperti berkurangnya kandungan protein ataupun karbohidrat. (SIDS,2004)

Penelitian ini bertujuan untuk menganalisis kandungan benzoil peroksida di dalam tepung terigu. Penggunaan benzoil peroksida di dalam tepung terigu di negara selain Indonesia sudah dilarang, namun di Indonesia masih banyak yang menambahkan benzoil peroksida ke dalam tepung sebagai pemutih tepung. 
Penelitian mengenai pemutih dalam tepung sudah banyak dilakukan, namun untuk benzoil peroksida belum banyak dilakukan. atas dasar inilah penelitian ini dilakukan. Selain itu penelitian ini dapat menambah informasi kepada masyarakat akan adanya zat berbahaya dalam tepung terigu sehingga masyarakat dapat memilih tepung yang baik untuk dikonsumsi.

\section{METODE}

Metode yang digunakan untuk menganalisis dan menetapkan kadar benzoil peroksida dalam tepung terigu menggunakan analisis kualitatif dan analisis kuantitatif dengan Spektrofometer UV. Tahapan penelitian pada penelitian ini meliputi: penyiapan bahan, preparasi sampel, validasi metode, analisis dan penetapan kadar benzoil peroksida.

\section{Penyiapan Bahan}

Penyiapan bahan meliputi pengumpulan bahan berupa 3 tepung terigu bermerk dan 3 tepung terigu non Merk yang diperoleh dari daerah Bandung, Jawa Barat.

\section{Validasi Metode}

Validasi metode dilakukan untuk membuktikan bahwa metode yang digunakan sesuai untuk analisis benzoil peroksida.Validasi metode terdiri dari:

Pembuatan Kurva Kalibrasi

Dibuat larutan benzoil peroksida dengan seri konsentrasi $0,5 \mu \mathrm{g} / \mathrm{mL} ; 1,4 \mu \mathrm{g} / \mathrm{mL} ; 2,3 \mu \mathrm{g} / \mathrm{mL} ; 3,2 \mu \mathrm{g} / \mathrm{mL}$; dan $5,0 \mu \mathrm{g} / \mathrm{mL}$ dengan cara diambil dari larutan standar $100 \mu \mathrm{g} / \mathrm{mL}$ dengan volume masing masing $0,05 \mathrm{~mL} ; 0,14 \mathrm{~mL} ; 0,23 \mathrm{~mL} ; 3,2 \mathrm{~mL}$ dan $0,50 \mathrm{~mL}$ kedalam labu ukur $10 \mathrm{~mL}$. Setelah itu, ditambahkan etanol $96 \%$ kedalam masing masing labu ukur sampai tanda batas. Kurva kalibrasi dibuat dari plot absorbansi (y) terhadap konsentrasi benzoil peroksida (x).

Batas Deteksi dan Batas Quantifikasi

Batas deteksi dan batas quantifikasi dapat dihitung secara statistik menggunakan data kurva kalibrasi.

\section{Akurasi}

Uji akurasi dilakukan dengan cara menambahkan larutan baku benzoil peroksida beberapa konsentrasi yaitu $1 \mu \mathrm{g} / \mathrm{mL}, 2 \mu \mathrm{g} / \mathrm{mL}$ dan $3 \mu \mathrm{g} / \mathrm{mL}$ pada $2,5 \mathrm{~mL}$ sampel yang dianalisis, lalu ditambah etanol $96 \%$ sampai dengan $5 \mathrm{~mL}$. Absorbansi larutan diukur pada panjang gelombang serapan maksimum benzoil peroksida. Hasil dari pengukuran ini identik dengan nilai sebenarnya yang dinyatakan dengan \% recovery.

\section{Presisi}

Uji presisi dilakukan dengan cara menambahkan larutan baku benzoil peroksida beberapa konsentrasi yaitu $1 \mu \mathrm{g} / \mathrm{mL}, 2 \mu \mathrm{g} / \mathrm{mL}$ dan $3 \mu \mathrm{g} / \mathrm{mL}$ pada $2,5 \mathrm{~mL}$ sampel yang dianalisis, lalu ditambah etanol $96 \%$ sampai dengan $10 \mathrm{~mL}$. Ukur absorbansi larutan pada panjang gelombang serapan maksimum benzoil peroksida. Perbedaan hasil penetapan berulang yang dilakukan menunjukan ketelitian hasil penetapan yang dapat dinyatakan dalam bentuk simpangan baku relatif atau koefisien korelasi.

$$
\mathrm{X} \text { Koefisien Variasi }=\overline{\mathrm{SD}} \times 100
$$

\section{Preparasi Sampel}

Preparasi Sampel meliputi pembuatan larutan-larutan dan reagen yang dibutuhkan untuk analisis dan penetapan kadar benzoil peroksida.

1. Pembuatan Larutan Baku Benzoil Peroksida $1000 \mu \mathrm{g} / \mathrm{mL}$.

Benzoil peroksida ditimbang sebanyak 0,025g, kemudian dimasukkan kedalam labu ukur $25 \mathrm{~mL}$ dan dilarutkan etanol 96\% sampai tanda batas. Setelah diperoleh larutan baku $1000 \mu \mathrm{g} / \mathrm{mL}$, kemudian dibuat pengenceran hingga diperoleh larutan $10 \mu \mathrm{g} / \mathrm{mL}$.

2. Pembuatan larutan KI $10 \%$

Kalium Iodida ditimbang sebanyak $1 \mathrm{~g}$, kemudian dimasukan kedalam beakerglass dan dilarutkan dengan aquadest sampai $10 \mathrm{~mL}$ aduk sampai semua larut dan homogen. 
3. Pembuatan suspensi Amilum $1 \%$

Amilum ditimbang sebanyak $0,1 \mathrm{~g}$, kemudian dimasukan kedalam beakerglass dan dilarutkan dengan aquadest sampai $10 \mathrm{ml}$, dididihkan sambil diaduk sampai homogen.

4. Pembuatan Larutan Sampel.

Ditimbang tepung terigu sampel sebanyak $0,5 \mathrm{~g}$, dimasukkan kedalam tabung reaksi dan ditambahkan $5 \mathrm{~mL}$ etanol $96 \%$. Kemudian, larutan sampel disonikasi selama 15 menit. Setelah selesai, larutan sampel disentrifugasi dengan kecepatan 7000rpm selama 20 menit. Larutan supernatant diambil setelah larutan disaring dengan kertas saring.

5. Penentuan Serapan Panjang Gelombang Maksimum

Dibuat larutan benzoil peroksida dengan konsentrasi $4 \mu \mathrm{g} / \mathrm{mL}$, dengan cara diambil dari larutan standar $100 \mu \mathrm{g} / \mathrm{mL}$ dengan volume $0,4 \mathrm{~mL}$ kedalam labu ukur $10 \mathrm{~mL}$. Setelah itu, ditambahkan etanol $96 \%$ kedalam labu ukur sampai tanda batas. Panjang gelombang serapan maksimum dari benzoil peroksidaditentukan pada panjang gelombang antara $200-400 \mathrm{~nm}$.

\section{Analisis dan Penetapan Kadar Benzoil Peroksida}

1. Analisis Kualitatif Benzoil Peroksida

Uji kualitatif dilakukan pada plat tetes menggunakan reagen larutan KI $10 \%$, asam fosfat $85 \%$ dan suspense amilum 1\%. Ambil larutan sampel uji masing-masing 2 tetes pada tempat yang berbeda pada plat tetes, untuk kontrol positif diambil larutan baku benzoil peroksida 2 tetes letakkan pada plat tetes lainnya dan untuk kontrol negatif ambil pelarut etanol 2 tetes letakan pada plat tetes yang masih kosong. Pada masing masing plat tetes yang sudah terisi, tetesi dengan asam fosfat 85\% 3tetes dan larutan KI 10\% 2 tetes, diamkan selama 2 menit. Setelah itu, tetesi dengan suspensi amilum 1 tetes, diamkan selama 10 menit. Reaksi positif akan menunjukan warna merah keunguan atau ungu gelap, sedangkan reaksi negatif menunjukan tidak berwarna.

2. Penetapan Kadar Benzoil Peroksida

Penetapan Kadar Sampel dilakukan dengan metode standar adisi penambahan baku 3 konsentrasi, dengan cara menambahkan larutan baku benzoil peroksida beberapa konsentrasi yaitu $1 \mu \mathrm{g} / \mathrm{mL}, 2 \mu \mathrm{g} / \mathrm{mL}$ dan $3 \mu \mathrm{g} / \mathrm{mL}$ pada $2,5 \mathrm{~mL}$ sampel yang dianalisis, lalu ditambah etanol $96 \%$ sampai dengan $5 \mathrm{~mL}$. Pengukura absorbansi larutan dilakukan pada panjang gelombang serapan maksimum benzoil peroksida, kemudian ditentukan persamaan regresi linieritas sampel. Hal ini dilakukan pada 6 sampel dengan perlakuan yang sama.

\section{HASIL}

\section{Penentuan Panjang Gelombang Maksimum dan Pembuatan Kurva Kalibrasi}

Tahap pertama yang dilakukan dalam analisis ini yaitu menentukan panjang gelombang maksimum benzoil peroksida. Hasil penentuan panjang gelombang maksimumbenzoil peroksida dapat dilihat pada gambar 1. Panjang gelombang serapan maksimum benzoil peroksida yang didapatkan pada konsentrasi larutan $4 \mu \mathrm{g} / \mathrm{mL}$ ialah $234 \mathrm{~nm}$ dengan absorbansi 0,50406.

Tahap kedua ialah pembuatan kurva kalibrasi dan menentukan linieritas suatu kurva. Linearitas menunjukkan kemampuan suatu metode analisis untuk memperoleh hasil pengujian yang sesuai dengan konsentrasi analit dalam sampel pada kisaran konsentrasi tertent(Emer \& Miller, 2005). Kurva kalibrasi dibuat dengan seri konsentrasi $0,5 \mu \mathrm{g} / \mathrm{mL}-5,0 \mu \mathrm{g} / \mathrm{mL}$, sebanyak 6 konsentrasi. Konsentrasi yang digunakan dapat dilihat dari Tabel.1.

\section{Validasi Metode}

Penentuan Batas Deteksi dan Batas Kuantitasi

Dari data kurva kalibrasi akan diperoleh beberapa parameter seperti persamaan regresi, batas deteksi, batas Kuantitasi, standar deviasi dari fungsi regresi dan koefisien variasi dari fungsi regresi. Hasil perhitungan batas deteksi dan batas Kuantitasi dapat dilihat pada Tabel.2. Diperoleh nilai batas deteksi $0,2099304 \mu \mathrm{g} / \mathrm{mL}$ dan batas Kuantitasi $0,6997679 \mu \mathrm{g} / \mathrm{mL}$. Hasil yang diperoleh menunjukkan kepekaan metode analisis yang digunakan.Standar deviasi dari fungsi regresi (Sxo) yang diperoleh ialah 0,0699768 dan koefisien variasi dari fungsi regresi (Vxo) ialah 2,5446107\%. Persyaratan Vxo untuk analit yang ada dalam matriks sampel ialah kurang dari atau sama dengan 5\%, hal tersebut 
menunjukan bahwa kurva yang dibuat memenuhi persyaratan.

\section{$\underline{\text { Akurasi }}$}

Pengukuran nilai akurasi dilihat dari nilai persentase perolehan kembali (persentase recovery) yang didapatkan. Dari data pada table 3 dan tabel 4 diperoleh nilai persentase perolehan kembali dalam rentang $90 \%-100 \%$ yaitu $94,6520 \%$ untuk standar adisi $1 \mu \mathrm{g} / \mathrm{mL}$ dengan nilai standar deviasi 1,5398 dan koevisien variasi 1,6268; 94,6886\% untuk standar adisi $2 \mu \mathrm{g} / \mathrm{mL}$ dengan nilai standar deviasi 1,1941 dan koevisien variasi 1,2611; serta 95,1526\% untuk standar adisi $3 \mu \mathrm{g} / \mathrm{mL}$ dengan nilai standar deviasi 0,5607 dan koevisien variasi 0,5893. Parameter ini dilakukan untuk melihat keakuratan dari metode yang kita gunakan, dalam hal ini metode yang digunakan sudah baik karena memiliki nilai persentase perolehan kembali yang sudah memenuhi syarat yang ditentukan yaitu antara $80-120 \%$ untuk sampel biologis atau analit dalam matriks sampel. (FI IV, 1994)

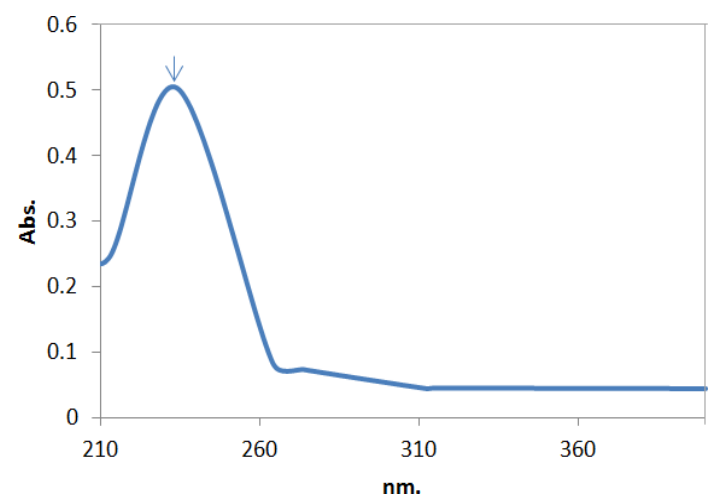

Gambar 1. Spektrum UV serapan benzoil peroksida

Tabel 1. Kurva Kalibrasi Larutan Standar Benzoil Peroksida

\begin{tabular}{cc}
\hline $\begin{array}{c}\text { Konsentrasi } \\
(\boldsymbol{\mu} \mathbf{g} / \mathbf{m L})\end{array}$ & Absorbansi \\
\hline 0,5 & 0,2840 \\
1,4 & 0,3690 \\
2,3 & 0,4590 \\
3,2 & 0,5310 \\
4,1 & 0,6240 \\
5,0 & 0,6900 \\
\hline
\end{tabular}

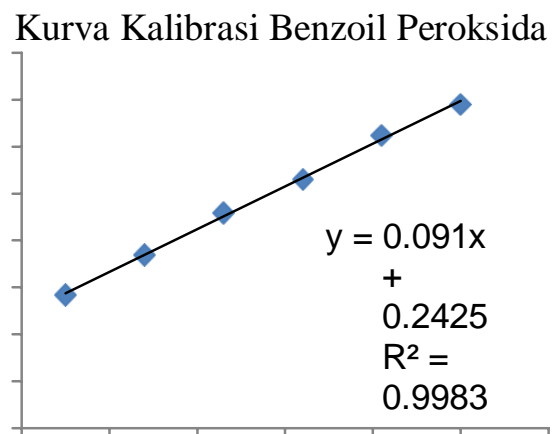

Gambar 2. Kurva Kalibrasi LarutanStandar Benzoil Peroksida

Tabel 2. Perhitungan batasdeteksi dan batas Kuantitasi

\begin{tabular}{|c|c|c|c|c|}
\hline Konsentrasi $(\boldsymbol{\mu g} / \mathbf{m L})$ & Absorbansi (y) & $\mathbf{y}^{\prime}$ & $\left|\mathbf{y}-\mathbf{y}^{\prime}\right|$ & $\left|\mathbf{y}-\mathbf{y}^{\prime}\right|^{2}$ \\
\hline 0,5 & 0,2840 & 0,2880 & $-0,0040$ & 0,00001600 \\
\hline 1,4 & 0,3690 & 0,3699 & $-0,0009$ & 0,00000081 \\
\hline
\end{tabular}


DOI: $10.47522 / j m k . v 1 i 2.14$

Jurnal Mitra Kesehatan (JMK)

ISSN: 2580-3379 (print); 2716-0874 (online)

69

\begin{tabular}{|c|c|c|c|c|}
\hline 2,3 & 0,4590 & 0,4518 & 0,0072 & 0,00005184 \\
\hline 3,2 & 0,5310 & 0,5337 & $-0,0027$ & 0,00000729 \\
\hline 4,1 & 0,6240 & 0,6156 & 0,0084 & 0,00007056 \\
\hline 5 & 0,6900 & 0,6975 & $-0,0075$ & 0,00005625 \\
\hline & & & $\Sigma$ & 0,0002028 \\
\hline & & & Sy/x & 0,00636789 \\
\hline & & & $\mathrm{BD}$ & $0,2099304 \mu \mathrm{g} / \mathrm{mL}$ \\
\hline & & & $\mathrm{BK}$ & $0,6997679 \mu \mathrm{g} / \mathrm{mL}$ \\
\hline & & & Sxo & 0,0699768 \\
\hline & & & Vxo & 2,5446107 \\
\hline
\end{tabular}

Tabel 3. Perhitungan akurasi dengan metode adisi secara intraday (dalam hari)

\begin{tabular}{|c|c|c|c|c|c|c|c|c|c|}
\hline \multirow{2}{*}{$\begin{array}{c}\text { Konsentrasi } \\
\text { Analit } \\
(\mu \mathrm{g} / \mathrm{mL})\end{array}$} & \multicolumn{3}{|c|}{ Absorbansi "y" } & \multicolumn{3}{|c|}{$\begin{array}{c}\text { Konsentrasi terukur " } \mathrm{x} " \\
(\mu \mathrm{g} / \mathrm{mL})\end{array}$} & \multicolumn{3}{|c|}{ \% Recovery } \\
\hline & Pagi & Siang & Sore & Pagi & Siang & Sore & Pagi & Siang & Sore \\
\hline \multirow{3}{*}{0} & 0,4050 & 0,4020 & 0,4030 & 1,7857 & 1,7527 & 1,7637 & & & \\
\hline & 0,4040 & 0,4010 & 0,4020 & 1,7747 & 1,7418 & 1,7527 & & & \\
\hline & 0,4030 & 0,3990 & 0,4040 & 1,7637 & 1,7198 & 1,7747 & & & \\
\hline Rata-rata & 0,4040 & 0,4007 & 0,4030 & 1,7747 & 1,7381 & 1,7637 & & & \\
\hline \multirow{3}{*}{1} & 0,4900 & 0,4860 & 0,4920 & 2,7198 & 2,6758 & 2,7418 & 93,4066 & 92,3077 & 97,8022 \\
\hline & 0,4900 & 0,4860 & 0,4900 & 2,7198 & 2,6758 & 2,7198 & 94,5055 & 93,4066 & 96,7033 \\
\hline & 0,4890 & 0,4850 & 0,4900 & 2,7088 & 2,6648 & 2,7198 & 94,5055 & 94,5055 & 94,5055 \\
\hline Rata-rata & 0.4897 & $\mathbf{0 , 4 8 5 7}$ & 0,4907 & 2,7161 & 2,6722 & 2,7271 & 94,1392 & 93,4066 & 96,3370 \\
\hline SD & & & & & & & 0,6345 & 1,0989 & 1,6786 \\
\hline $\mathrm{KV}$ & & & & & & & 0,6739 & 1,1765 & 1,7424 \\
\hline \multirow{3}{*}{2} & 0,5780 & 0,5710 & 0,5760 & 3,6868 & 3,6099 & 3,6648 & 95,0549 & 92,8571 & 95,0549 \\
\hline & 0,5780 & 0,5720 & 0,5750 & 3,6868 & 3,6209 & 3,6538 & 95,6044 & 93,9560 & 95,0549 \\
\hline & 0,5790 & 0,5690 & 0,5760 & 3,6978 & 3,5879 & 3,6648 & 96,7033 & 93,4066 & 94,5055 \\
\hline Rata-rata & $\mathbf{0 , 5 7 8 3}$ & $\mathbf{0 , 5 7 0 7}$ & 0,5757 & 3,6905 & 3,6062 & 3,6612 & 95,7875 & 93,4066 & 94,8718 \\
\hline $\mathrm{SD}$ & & & & & & & $\mathbf{0 , 8 3 9 3}$ & 0,5495 & $\mathbf{0 , 3 1 7 2}$ \\
\hline KV & & & & & & & 0,8762 & 0,5882 & 0,3344 \\
\hline \multirow{3}{*}{3} & 0,6620 & 0,6620 & 0,6630 & 4,6099 & 4,6099 & 4,6209 & 94,1392 & 95,2381 & 95,2381 \\
\hline & 0,6660 & 0,6610 & 0,6600 & 4,6538 & 4,5989 & 4,5879 & 95,9707 & 95,2381 & 94,5055 \\
\hline & 0,6660 & 0,6610 & 0,6600 & 4,6538 & 4,5989 & 4,5879 & 96,3370 & 95,9707 & 93,7729 \\
\hline Rata-rata & 0,6647 & 0,6613 & 0,6610 & 4,6392 & 4,6026 & 4,5989 & 95,4823 & 95,4823 & 94,5055 \\
\hline $\mathrm{SD}$ & & & & & & & 1,1775 & 0,4230 & 0,7326 \\
\hline $\mathrm{KV}$ & & & & & & & 1,2332 & 0,4430 & 0,7752 \\
\hline
\end{tabular}

$y=0,091 x+0,2425$

Tabel 4. Perhitungan rata-rata akurasi dengan metode adisi secara intraday (dalam hari)

\begin{tabular}{|c|c|c|c|c|c|c|}
\hline $\begin{array}{c}\text { Konsentrasi } \\
\text { Sebenarnya } \\
(\mu \mathrm{g} / \mathrm{mL})\end{array}$ & Absorbansi & $\begin{array}{c}\text { Konsentrasi } \\
\text { terukur } \\
(\mu \mathrm{g} / \mathrm{mL})\end{array}$ & $\begin{array}{c}\% \\
\text { Recovery }\end{array}$ & Rata- rata & SD & KV \\
\hline
\end{tabular}




\begin{tabular}{|c|c|c|c|c|c|c|}
\hline \multirow{3}{*}{0} & 0,4040 & 1,7747 & & & & \\
\hline & 0,4007 & 1,7385 & & & & \\
\hline & 0,4030 & 1,7637 & & & & \\
\hline \multirow{3}{*}{1} & 0,4897 & 2,7165 & 94,1758 & \multirow{3}{*}{94,6520} & \multirow{3}{*}{1,5398} & \multirow{3}{*}{1,6268} \\
\hline & 0,4857 & 2,6725 & 93,4066 & & & \\
\hline & 0,4907 & 2,7275 & 96,3736 & & & \\
\hline \multirow{3}{*}{2} & 0,5783 & 3,6901 & 95,7692 & \multirow{3}{*}{94,6886} & \multirow{3}{*}{1,1941} & \multirow{3}{*}{1,2611} \\
\hline & 0,5707 & 3,6066 & 93,4066 & & & \\
\hline & 0,5757 & 3,6615 & 94,8901 & & & \\
\hline \multirow{3}{*}{3} & 0,6647 & 4,6396 & 95,4945 & \multirow{3}{*}{95,1526} & \multirow{3}{*}{0,5607} & \multirow{3}{*}{0,5893} \\
\hline & 0,6613 & 4,6022 & 95,4579 & & & \\
\hline & 0,6610 & 4,5989 & 94,5055 & & & \\
\hline
\end{tabular}

Perolehan kembali $(\%)=\underline{\mathrm{Ct}-\mathrm{Ct} 0}$

$$
\text { Cs }
$$

Keterangan:

$\mathrm{Ct}=$ Konsentrasi terukur setelah penambahan standar $(\mu \mathrm{g} / \mathrm{mL})$

$\mathrm{Ct} 0=$ Konsentrasi terukur sebelum penambahan standar $(\mu \mathrm{g} / \mathrm{mL})$

Cs $=$ Konsentrasi Sebenarnya $(\mu \mathrm{g} / \mathrm{mL})$

Tabel 5. Perhitungan presisi dengan metode adisi secara intraday (dalam hari)

\begin{tabular}{|c|c|c|c|c|c|c|}
\hline \multirow{2}{*}{$\begin{array}{c}\text { Konsentrasi } \\
\text { Analit } \\
(\mu \mathrm{g} / \mathrm{mL})\end{array}$} & \multicolumn{3}{|c|}{ Absorbansi } & \multicolumn{3}{|c|}{ Konsentrasi terukur $(\mu \mathrm{g} / \mathrm{mL})$} \\
\hline & Pagi & Siang & Sore & Pagi & Siang & Sore \\
\hline \multirow{6}{*}{0} & 0,4050 & 0,4030 & 0,4040 & & & \\
\hline & 0,4040 & 0,4020 & 0,4050 & & & \\
\hline & 0,4040 & 0,4010 & 0,4030 & & & \\
\hline & 0,4050 & 0,3990 & 0,4020 & & & \\
\hline & 0,4040 & 0,4010 & 0,4040 & & & \\
\hline & 0,4030 & 0,3980 & 0,4000 & & & \\
\hline \multirow{6}{*}{2} & 0,5750 & 0,5740 & 0,5740 & 1,8681 & 1,8791 & 1,8681 \\
\hline & 0,5770 & 0,5710 & 0,5750 & 1,9011 & 1,8571 & 1,8681 \\
\hline & 0,5800 & 0,5720 & 0,5760 & 1,9341 & 1,8791 & 1,9011 \\
\hline & 0,5780 & 0,5690 & 0,5750 & 1,9011 & 1,8681 & 1,9011 \\
\hline & 0,5780 & 0,5730 & 0,5760 & 1,9121 & 1,8901 & 1,8901 \\
\hline & 0,5790 & 0,5720 & 0,5740 & 1,9341 & 1,9121 & 1,9121 \\
\hline & & & $\bar{X}$ & 1,90842 & 1,88095 & 1,89011 \\
\hline & & & SD & 0,02474 & 0,01893 & 0,01839 \\
\hline & & & $\mathrm{KV}$ & 1,29612 & 1,00627 & 0,97286 \\
\hline
\end{tabular}

$y=0,091 x+0,2425$

Tabel 6. Perhitungan Presisi dengan metode adisi secara interday (antar hari)

\begin{tabular}{|l|l|l|}
\hline Konsentrasi & Absorbansi & Konsentrasi terukur $(\mu \mathrm{g} / \mathrm{mL})$ \\
\hline
\end{tabular}




\begin{tabular}{|c|c|c|c|c|c|c|}
\hline $\begin{array}{c}\text { Analit } \\
(\mu \mathrm{g} / \mathrm{mL})\end{array}$ & $\begin{array}{l}\text { Hari } \\
\text { ke-1 }\end{array}$ & $\begin{array}{l}\text { Hari } \\
\text { ke-2 }\end{array}$ & $\begin{array}{l}\text { Hari } \\
\text { ke-3 }\end{array}$ & Hari ke- 1 & Hari ke-2 & Hari ke- 3 \\
\hline \multirow{6}{*}{0} & 0,4050 & 0,4044 & 0,4030 & & & \\
\hline & 0,4040 & 0,4037 & 0,4020 & & & \\
\hline & 0,4040 & 0,4027 & 0,4010 & & & \\
\hline & 0,4050 & 0,4020 & 0,3990 & & & \\
\hline & 0,4040 & 0,4030 & 0,4010 & & & \\
\hline & 0,4030 & 0,4030 & 0,3980 & & & \\
\hline \multirow{6}{*}{2} & 0,5750 & 0,5743 & 0,5740 & 1,8681 & 1,8670 & 1,8791 \\
\hline & 0,5770 & 0,5743 & 0,5710 & 1,9011 & 1,8747 & 1,8571 \\
\hline & 0,5800 & 0,5760 & 0,5720 & 1,9341 & 1,9044 & 1,8791 \\
\hline & 0,5780 & 0,5740 & 0,5690 & 1,9011 & 1,8901 & 1,8681 \\
\hline & 0,5780 & 0,5757 & 0,5730 & 1,9121 & 1,8978 & 1,8901 \\
\hline & 0,5790 & 0,5750 & 0,5720 & 1,9341 & 1,8901 & 1,9121 \\
\hline & & & X & 1,90842 & 1,88736 & 1,88095 \\
\hline & & & SD & 0,02474 & 0,01405 & 0,01893 \\
\hline & & & $\mathrm{KV}$ & 1,29612 & 0,7445 & 1,00627 \\
\hline
\end{tabular}

$y=0,091 x+0,2425$

\section{Presisi}

Berdasarkan perhitungan yang disajikan pada tabel 5 dan tabel 6. Diperoleh data koefisien variasi pengerjaan dalam hari yaitu 1,29612 pada waktu pagi; 1,00627 pada waktu siang; dan 0,97286 pada waktu sore hari.Kemudian data koefisien variasi pengerjaan antar hari yaitu 1,29612 untuk hari pertama; 0,7445 untuk hari kedua; dan 1,00627 untuk hari ketiga.

\section{Pengukuran Kadar Sampel}

Pengukuran kadar sampel tepung terigu yang dilakukan terhadap 6 sampel yang diambil didaerah Jatinangor meliputi 3 sampel tepung terigu bermerk dan 3 sampel tepung terigu non nerk. Sebelum penentuan kadar, dilakukan analisis kualitatif terlebih dahulu dengan mereaksikansampel menggunakan KI (Kalium Iodida) dalam medium asam fosfat dengan amilum sebagai indikatornya. Benzoil peroksida merupakan senyawa oksidator yang akan mengoksidasi KI dalam suasana asam dan menghasilkan I2 (Iodium) dan nantinya akan dideteksi oleh amilum sebagai indikatornya dengan menghasilkan warna merah keunguan atau biru gelap. Dari pengujian ini, seluruh sampel menghasilkan warna merah keunguan yang menunjukan bahwa sampel positif mengandung benzoil peroksida.Tabel 7 dan gambar 3 menunjukkan hasil uji kualitatif sampel.

Langkah terakhir yaitu penetapan kadar analit dalam sampel dengan metode standar adisi. Hal ini dilakukan agar telihat penambahan absorban seiring dengan penambahan baku didalam sampel analisis. Pengukuran dilakukan secara triplo.

Tabel 7. Uji kualitatif sampel

\begin{tabular}{|c|c|c|}
\hline Sampel & Reaksi warna & Hasil \\
\hline Sampel Merk A & Merah keunguan bening & + \\
\hline Sampel Merk B & Merah keunguan agak keruh & + \\
\hline Sampel Merk C & Merah keunguan agak keruh & + \\
\hline Sampel Non merk A & Merah keunguan keruh & + \\
\hline Sampel Non merk B & Merah keunguan agak keruh & + \\
\hline Sampel Non merk C & Merah keunguan keruh & + \\
\hline
\end{tabular}




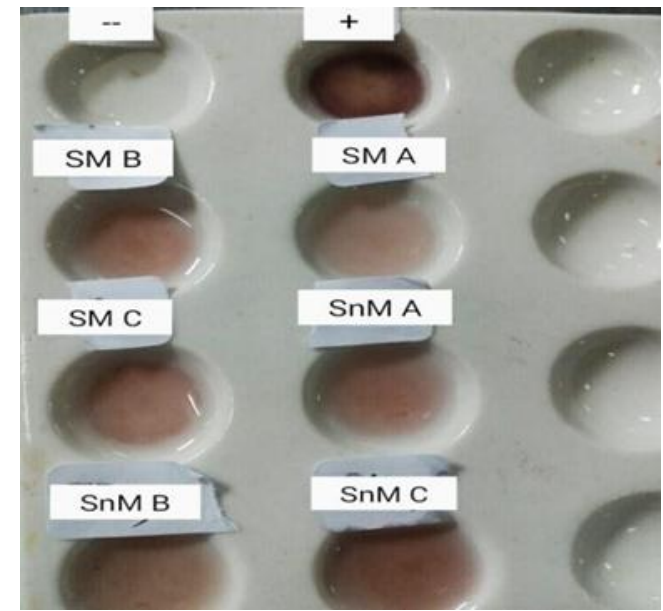

Gambar 3. Uji kualitatif sampel

Tabel 8. Data kadar analit dalam sampel tepung terigu

\begin{tabular}{|c|c|c|}
\hline No & Sampel & Kadar $(\mathbf{m g} / \mathbf{k g})$ \\
\hline 1 & Sampel Merk A & 28,88 \\
\hline 2 & Sampel Merk B & 48,36 \\
\hline 3 & Sampel Merk C & 71,90 \\
\hline 4 & Sampel Non Merk A & 87,00 \\
\hline 5 & Sampel Non Merk B & 75,08 \\
\hline 6 & Sampel Non Merk C & 83,52 \\
\hline
\end{tabular}

\section{PEMBAHASAN}

Benzoil peroksida merupakan senyawa organik golongan peroksida yang disalahgunakan sebagai pemutih tepung (pematang tepung), dalam hal ini ialah tepung terigu. Benzoil peroksida cukup beresiko jika digunakan dalam jumlah yang tinggi, karena dapat menyebabkan gangguan kesehatan. Selain itu, Benzoil peroksida merupakan senyawa reaktif dan mudah mengalami penguraian serta dapat mengurangi nilai nutrisi jika ditambahkan dalam tepung terigu. Pada penelitian ini, Benzoil peroksida dianalisis dengan metode spektrofotometri UV yang mempunyai rentang panjang gelombang 200-400 nm. Selain itu, benzoil peroksida mempunyai kromofor sehingga dapat dianalisis dengan metode spektrofotometri UV.

Panjang gelombang serapan maksimum benzoil peroksida yang didapatkan pada konsentrasi larutan $4 \mu \mathrm{g} / \mathrm{mL}$ ialah $234 \mathrm{~nm}$ dengan absorbansi 0,50406. Panjang gelombang serapan maksimum tersebut sesuai dengan panjang gelompang benzoil peroksida menurut pustaka yaitu 230 (Gupta et al., 2009). Panjang gelombang hasil penentuan panjang gelombang maksimum digunakan pada tahap selanjutnya.

Pada penelitian ini dibuat seri konsentrasi $0,5 \mu \mathrm{g} / \mathrm{mL}-5,0 \mu \mathrm{g} / \mathrm{mL}$, dimana pada konsentrasi tersebut memberikan absorbansi yang sesuai dengan hukum lambert beers yaitu pada rentang 0,2-0,8. Persamaan regresi linier yang didapatkan ialah $\mathrm{y}=0,091 \mathrm{x}+0,2425$, dengan nilai koefisien korelasi sebesar 0,99836 dimana nilai sudah menunjukkan hubungan yang linier antara konsentrasi benzoil peroksida dengan absorbansinya karena mendekati nilai 1,0 sehingga dapat dikatakan berbanding lurus. Semakin besar konsentrasi benzoil peroksida, absorbansi akan semakin meningkat secara konstan. Akurasi adalah ukuran yang menunjukkan derajat kedekatan hasil analis dengan kadar analit yang sebenarnya.

Metode pengukuran akurasi yang digunakan adalah metode adisi karena tidak memungkinkan membuat sampel plasebo. Yaitu kadar benzoil peroksida pada sampel diukur,kemudian ditambahkan benzoil peroksida dengan jumlah tertentu dan diukur kadar benzoil peroksida total pada sampel. Kemudian dihitung selisih kadar benzoil peroksidatotal dengan kadar benzoil peroksida pada sampel. Sampel dibuat 3 replikat dengan perlakuan yang sama. Rasio perbandingan benzoil peroksida yang terukur dengan benzoil peroksida yang ditambahkan adalah nilai perolehan kembali yang menunjukkan keakurasian metode.Pengukuran akurasi dengan metode standar adisi secara intraday. Intraday merupakan pengulangan yang dilakukan tiap jam tertentu dalam satu hari. 
Presisi adalah ukuran yang menunjukkan derajat kesesuaian antara hasil uji individual, diukur melalui penyebaran hasil individual dari rata-rata jika prosedur diterapkan secara berulang pada sampel-sampel yang diambil dari campuran yang homogen. Presisi diukur sebagai simpangan baku atau simpangan baku relatif (koefisien variasi). (Harmita, 2004)

Dalam pengukuran presisi dengan metode standar adisi secara intraday dan interday. Intraday merupakan pengulangan yang dilakukan tiap jam tertentu dalam satu hari, sedangkan interday merupakan pengulangan yang dilakukan tiap hari pada jam tertentu dalam beberapa hari. Penentuan presisi menggunakan metode standar adisi dengan penambahan baku benzoil peroksida kedalam sampel dengan konsentrasi $2 \mu \mathrm{g} / \mathrm{mL}$. Prosedur pengerjaan presisi sama seperti akurasi, perbedaannya presisi menggunakan penambahan standar pada sampel hanya 1 konsentrasi yaitu $2 \mu \mathrm{g} / \mathrm{mL}$ dan dibuat 6 kali replikat dengan perlakuan yang sama. Sedangkan untuk penentuan presisi dilihat dari nilai persentase koefisien variasi.Dari nilai persentase koefisien variasi yang diperoleh sudah memenuhi syarat yang ditentukan dimana nilai persentasekoefisien variasinya kurang dari 2\% (Harmita, 2004). Nilai koefisien variasi pada pengerjaan dalam hari yang paling baik ialah pada waktu sore hari sebesar 97,286\%dan nilai koefisien variasi pada pengerjaan antar hari yang paling baik ialah pada hari kedua sebesar $74,45 \%$. Karena semakin kecil nilai koefisien variasi, akan semakin presisi.

Dari hasil penelitian yang telah dilakukan, dapat diketahui kadar analit dalam sampel seperti yang ada pada tabel 8. Menurut Codex Alimentarius Commission yang didirikan oleh FAO, batas penggunaan Benzoil peroksida dalam tepung terigu ialah kurang dari $75 \mathrm{mg} / \mathrm{kg}$. Dari data yang sudah didapatkan, sampel non Merk A, sampel non Merk B dan sampel non Merk C melewati batas penggunaan benzoil peroksida yang ditentukan.

\section{KESIMPULAN}

Dari penelitian analisis benzoil peroksida yang dilakukan dengan metode spektrofotometri UV, diperoleh panjang gelombang maksimum Benzoil Peroksida 234nm dengan persamaan $\mathrm{y}=0,09104 \mathrm{x}+$ 0,24247 dan nilai koefisien korelasi (r) sebesar 0,99836. Dengan nilai parameter linieritas, meliputi: batas deteksi $0,2099304 \mu \mathrm{g} / \mathrm{mL}$, batas Kuantitasi $0,6997679 \mu \mathrm{g} / \mathrm{mL}$, standar deviasi dari fungsi regresi (Sxo) yang diperoleh ialah 0,0699768 dan koefisien variasi dari fungsi regresi (Vxo) ialah 2,5446107\%. Persentase recovery berada pada rentang $90-100 \%$ untuk pengukuran akurasi, serta nilai KV nya kurang dari $2 \%$ untuk pengukuran presisi.Sehingga metode spektrofotometri UV dapat digunakan untuk analisis benzoil peroksida. Pada sampel tepung terigu bermerk kadar Benzoil peroksida kurang dari $75 \mathrm{mg} / \mathrm{kg}$, sedangkan pada sampel tepung terigu non Merk yang beredar kadar benzoil peroksida lebih dari $75 \mathrm{mg} / \mathrm{kg}$. Sehingga dapat disimpulkan sampel tepung terigu non Merk tidak memenuhi syarat.

\section{UCAPAN TERIMA KASIH}

Terima kasih kepada Sekolah Tinggi Farmasi Bandung yang telah berkontribusi sehingga penelitian ini dapat berlangsung.

\section{REFERENSI}

Muchtadi TR dan Sugiyono. (1992). Petunjuk Laboratorium Ilmu Pengetahuan Bahan Pangan . Bogor: Institut Pertanian Bogor.

Nurmala, T. (1980). Budidaya Tanaman Gandum. Bandung: PT Karya Nusantara Jakarta.

Benzoyl Peroxide.SIDS Initial Assesment Report.Geneva: United Nations Environment Programme, April 2004

Harmita. (2004). Petunjuk Pelaksanaan Validasi Metode Dan Cara Perhitungannya. Majalah Ilmu Kefarmasian, Desember., Vol. 1, 1 (3). 117 - 135. Departemen Farmasi FMIPA-UI.

Gandjar, G.I \& Rohman, A. 2007. Kimia Farmasi Analisis. Pustaka Belajar. Yogyakarta.

Ermer, J.H. and Miller, McB. 2005.Method Validation in Pharmaceutical Analysis.A Guide to Best Practice.Wiley-Vch. Verlag GmbH \& Co. KGaA.Weinheim.

Depkes RI. 1994. Farmakope Indonesia edisi IV.

Gupta, A., Gulati, M., Pandey, KN.,.2009. A Validated UV Spectrophotometric Method For Simultaneous Estimation Of Tritinoin And Benzoyl Peroxide In Bulk and Semi Solid Dosage Form. RASAYAN J.Chem Vol.2, No.3, 649- 654, ISSN: 0974-1496, CODEN: RJCABP. 